\title{
PENGARUH PROMOSI KESEHATAN TERHADAP MOTIVASI PASIEN HIPERTENSI TENTANG PELAKSANAAN DIET HIPERTENSI DI POLIKLINIK PENYAKIT DALAM RS. RAJAWALI BANDUNG
}

\author{
Dadang Darmawan ${ }^{1}$ Siti Zulfa ${ }^{2}$
}

\begin{abstract}
ABSTRAK
Meningkatnya arus globalisasi disegala bidang dengan perkembangan teknologi dan industri telah banyak membuat perubahan pada perilaku dan gaya hidup pada masyarakat. Perubahan gaya hidup, sosial ekonomi, industralisasi dapat memacu meningkatnya penyakit seperti hipertensi. Hipertensi merupakan penyebab utama gagal jantung, stroke dan ginjal. Disebut sebagai "pembunuh diam-diam" karena orang hipertensi tidak menampakkan gejala (Brunner \& Suddarth, 2002: 896). Hipertensi adalah gangguan sistem peredaran darah yang menyebabkan kenaikan tekanan darah di atas normal yaitu $140 / 90 \mathrm{mmHg}$. Kecenderungan peningkatan prevalensi menurut peningkatan usia. Prevalensi 6 - 15\% pada orang dewasa sebagai proses degeneratif, hipertensi hanya ditemukan pada golongan orang dewasa. Banyak penderita hipertensi diperkirakan sebesar 15 juta penduduk Indonesia yang kontrol hanya 4\%. Terdapat 50\% penderita hipertensi tidak menyadari hipertensi (Tyas Kusuma Dewi, 2013). Diet adalah pembatasan asupan nutrisi tertentu. ( wikipedia.org/diet) Pengendalian hipertensi dengan diet tujuannya untuk melakukan pencegahan primer, deteksi awal dan penanganan memadai untuk mencegah terjadinya komplikasi. Dalam pelaksanaan diet perlu adanya motivasi dari dalam diri penderita maupun dari keluarga. Motivasi adalah dorongan internal dan eksternal dari tiap individu sebelum melakukan tindakan atau perilaku. Rumah Sakit Rajawali merupakan Rumah Sakit Yayasan Kemanusiaaan yang memberikan pelayanan asuhan keperawatan. Data Penyakit di Poliklinik Penyakit Dalam RS Rajawali Bandung Bulan Mei - Oktober 2013 adalah : hipertensi 410 (46.17\%), Typoid 57 (6.42\%), DM type II 321 (36.15\%) Hepatitis 33 (3.72\%) dan Decomp 67 (7.55\%) Dapat disimpulkan jika Hipertensi mencapai urutan paling tinggi sebanyak 410 (46.17\%). Penelitian dilakukan dengan menilai motaivasi sebelum dan sesudah dilakukan promosi kesehatan. Metode yang digunakan adalah Pre experiment. Hasil penelitian terdapat perbedaan rata-rata motivasi pasien hipertensi sebelum dilakukan promosi kesehatan tentang pelaksanaan diet hipertensi adalah 1,56 dengan standar deviation 0,128 sedangkan setelah diberikan pendidikan kesehatan 1,69 dengan standar deviation $0,120 \mathrm{P}_{\text {value }}=0,432>\alpha(0,05)$. Rentang nilai mean 0,13 sehingga dapat disimpulkan bahwa promosi kesehatan berpengaruh terhadap motivasi pasien hipertensi tentang pelaksanaan diet hipertensi di Poliklinik Penyakit Dalam RS. Rajawali Bandung
\end{abstract}

Kata Kunci : Motivasi, diet hipertensi, promosi kesehatan 


\section{PENDAHULUAN}

Meningkatnya arus globalisasi disegala bidang dengan perkembangan teknologi dan industri telah banyak membuat perubahan pada perilaku dan gaya hidup pada masyarakat. Perubahan gaya hidup, sosial ekonomi, industralisasi dapat memacu meningkatnya penyakit seperti hipertensi. Hipertensi merupakan penyebab utama gagal jantung, stroke dan ginjal. Disebut sebagai "pembunuh diam-diam" karena orang hipertensi tidak menampakkan gejala (Brunner \& Suddarth, 2002: 896).

Hipertensi adalah gangguan sistem peredaran darah yang menyebabkan kenaikan tekanan darah di atas normal yaitu 140/90 $\mathrm{mmHg}$. Kecenderungan peningkatan prevalensi menurut peningkatan usia. Prevalensi 6 - 15\% pada orang dewasa sebagai proses degeneratif, hipertensi hanya ditemukan pada golongan orang dewasa. Banyak penderita hipertensi diperkirakan sebesar 15 juta penduduk Indonesia yang kontrol hanya $4 \%$. Terdapat $50 \%$ penderita hipertensi tidak menyadari hipertensi (Tyas Kusuma Dewi, 2013).

Sebagian besar kasus hipertensi di masyarakat belum terdeteksi dan tidak diketahui penyebabnya. Keadaan ini tentu sangat berbahaya yang menyebabkan kematian dan berbagai komplikasi seperti stroke. Hipertensi merupakan penyebab kematian nomor tiga setelah penyakit stroke dan tuberkulosis mencapai $6,7 \%$ dari populasi kematian pada semua umur di Indonesia. Prevalensi hipertensi secara nasional mencapai $31,7 \%$. Pada kelompok umur 25 - 34 tahun sebesar $7 \%$ naik menjadi $16 \%$ pada kelompok umur 35 - 44 tahun dan kelompok umur 65 tahun atau lebih menjadi $29 \%$ (Survey Kesehatan Nasional , 2007 dalam Eka 2011: 3)

World Health Organization (WHO) tahun 2012 menunjukkan hipertensi adalah salah satu kontributor paling penting untuk penyakit jantung dan stroke yang bersama-sama menjadi penyebab kematian dan kecacatan nomor satu. Hipertensi memberikan kontribusi untuk hampir 9,4 juta kematian akibat penyakit 
kardiovaskuler setiap tahun. Hal ini juga meningkatkan risiko kondisi seperti gagal ginjal dan kebutaan. Hipertensi diperkirakan mempengaruhi lebih dari satu dari tiga orang dewasa berusia 25 tahun ke atas, atau sekitar satu miliar orang di seluruh dunia (WHO 2012).

Prevalensi hipertensi tertinggi di dunia berada di negara Afrika (46\% orang dewasa) sedangkan prevalensi terendah ditemukan di negara Amerika (35\% orang dewasa) menurut WHO (2012). Data tersebut dapat dipastikan bahwa negara yang berpenghasilan tinggi memiliki prevalensi rendah hipertensi (35\% orang dewasa) dibandingkan kelompok pendapatan rendah dan menengah $(40 \%$ orang dewasa) berkat kebijakan publik multisektoral sukses dan akses yang lebih baik ke perawatan kesehatan bagi Negara dengan penghasilan tinggi.

Hasil Riset Kesehatan Dasar (Riskesdas) tahun 2007 menunjukkan peningkatan yang tinggi. Hal ini terlihat dari hasil pengukuran tekanan darah pada usia 18 tahun ke atas ditemukan prevalensi hipertensi
diIndonesia sebesar $31,7 \%$, dimana hanya $7,2 \%$ penduduk yang sudah mengetahui memiliki hipertensi dan hanya $0,4 \%$ kasus yang minum obat hipertensi.

Rumah Sakit Rajawali merupakan Rumah Sakit Yayasan Kemanusiaaan yang memberikan pelayanan asuhan keperawatan. Data Penyakit di Poliklinik Penyakit Dalam RS Rajawali Bandung Bulan Mei Oktober 2013 adalah : hipertensi 410 (46.17\%), Typoid 57 (6.42\%), DM type II 321 (36.15\%) Hepatitis 33 (3.72\%) dan Decomp 67 (7.55\%) Dapat disimpulkan jika Hipertensi mencapai urutan paling tinggi sebanyak $410(46.17 \%)$.

Penataksanaan hipertensi diperlukan untuk mencegah keberlangsungan kerusakan organ target dalam waktu lama sehingga menurunkan kesakitan dan kematian. Berbagai studi merekomendasikan bahwa hipertensi dapat diturunkan dengan melakukan modifikasi gaya hidup, mengontrol berat badan, tekanan darah, latihan/olah raga, diet sehat, menurunkan konsumsi alcohol dan 
rokok. Akhir-akhir ini direkomendasikan penekanan pencegahan, deteksi dini, evaluasi dan penatalaksanaan penyakit hipertensi harus dilakukan melalui promosi kesehatan dan modifikasi gaya hidup sehat (Joint National Committee, 2003).

Studi-studi lain menunjukkan, diet tinggi sodium bisa meningkatkan tekanan darah. Semakin sedikit sodium yang dikonsumsi, semakin baik tekanan darah, meskipun menggunakan obat pengontrol tekanan darah.

Dampak yang timbul bila tidak menjalankan diet hipertensi terhadap tubuh kita dapat menyebabkan gejala stroke, jika keadaan ini tidak diketehui sejak dini maka tidak menutup kemungkinan hal ini dapat mengakibatkan terjadinya kerusakan permanen pada otak. Selain stroke juga bisa menyebabkan gagal jantung, dimana ada penurunan gerak jantung dalam memompa darah sehingga jantung dalam memompa darah tidak dapat memenuhi keperluan tubuh yang terus menerus membutuhkan oksigen dan zat nutrisi. Dampak yang selanjutnya penyakit arteri coroner, dimana penyakit ini terjadi karena adanya penyempitan/penyumbatan pada arteri (Martuti : 2009). Sedangkan hasil penelitian Fazidah (2005) menemukan sebanyak $90,9 \%$ penderita stroke mempunyai riwayat hipertensi.

Hasil studi pendahuluan menunjukkan bahwa: 5 orang pasien mengatakan bahwa mereka mengetahui mengenai diet hipertensi tetapi mereka malas untuk menjalankannya dikarenakan suka makanan yang mengandung banyak garam seperti ikan asin, 2 orang pasien lainnya mengatakan bahwa tidak nikmat kalau harus makan dengan garam yang sedikit, karena tidak ada rasanya, dan 3 orang pasien lainnya mengatakan bahwa mereka menjalankan diet yang seharusnya karena mereka termotivasi ingin lekas sembuh.

Motivasi secara umum mengacu pada adanya kekuatan dorongan yang menggerakkan kita untuk melakukan sesuatu. Oleh karena itu motivasi berhubungan dengan hasrat, keinginan, dorongan dan tujuan (Notoatmodjo: 2005). Motivasi dibagi 
menjadi 2 jenis yaitu motivasi intrinsic dan motivasi ekstrinsik. Motivasi instrinsik berasal dari dalam diri sendiri, biasanya timbul dari perilaku yang dapat memenuhi kebutuhan sehingga manusia menjadi puas. Motivasi ekstrinsik berasal dari luar yang merupakan pengaruh dari luar atau lingkungan. Perilaku yang dilakukan dengan motivasi ekstrinsik penuh dengan kekhawatiran, kesangsian apabila tidak tercapai kebutuhan.

Pendekatan edukasi dengan promosi kesehatan merupakan salah satu salah satu cara terbaik untuk memberikan informasi dan motivasi yang dapat dipercaya pada masyarakat dan membantu individu mengembangkan kemampuan membuat keputusan dan memberikan pencitraan pada masyarakat untuk menggali dan mengembangkan sikap dan tindakan yang semestinya (Kozier \& Erb, 2008: Naidono \& Wills, 2000).

Promosi kesehatan yang dilakukan perawat efektif dalam memanajemen penyakit kronis seperti hipertensi karena perawat menggunakan pengetahuan dan skill yang dimiliki untuk memberikan asuhan proses perawatan (Yura \& Walsh, 1983 dalam Hong 20,10). Berdasarkan hasil studi pendahuluan melalui wawancara terhadap 10 responden diketahui bahwa 8 dari 10 responden menyatakan bahwa 8 orang setuju dengan pengetahuan mempengaruhi motivasi dalam pelaksanaan diit hipertensi dan 2 orang menyatakan tidak setuju bahwa pengetahuan mempengaruhi motivasi dalam pelaksanaan diit hipertensi. 4 dari 10 responden menyatakan pernah mendapat penyuluhan mengenai Pelaksanaan diet hipertensi, namun mereka tidak mengetahui mengenai Pelaksanaan diet, sedangkan 6 orang mengatakan pernah mendapatkan penyuluhan dan 3 orang hanya tahu tentang tanda dan gejala hipertensi, 3 orang tahu tentang definisi penyakit hipertensi. Oleh sebab itu maka perlu dilakukan penelitian tentang: "Pengaruh Promosi Kesehatan Terhadap Motivasi Pasien Hipertensi Tentang Pelaksanaan Diet Hipertensi di 
Poliklinik Penyakit Dalam RS. mendapatkan informasi atau jawaban Rajawali Bandung?"

\section{METODOLOGI PENELITIAN}

\section{Desain Penelitian}

Desain penelitian eksperimen yang digunakan adalah desain eksperimen One Group Pretest Posttest Design, jadi dalam desain penelitian eksperimen One Group Pretest Posttest Design ini sudah dilakukan observasi pertama (pretest) sehingga peneliti dapat menguji perubahan-perubahan yang terjadi setelah adanya perlakuan, tetapi dalam desain penelitian ini tidak ada kelompok kontrol (pembanding). Pretest merupakan pengukuran motivasi pasien hipertensi sebelum dilakukan atau diberikan intervensi (pemberian promosi kesehatan tentang diet hipertensi). Selanjutnya posttes adalah pengukuran motivasi pasien hipertensi setelah diberikan intervensi.

\section{Metode Pengumpulan Data}

Data yang digunakan adalah data primer yaitu data yang diambil secara langsung dari responden dengan menggunakan metode angket berupa daftar pernyataan yang diajukan secara tertulis kepada responden untuk dengan cara menyebarkan kuesioner kepada responden, dimana pemberian kuesioner dilakukan sebanyak 2 kali, yang pertama pada saat pre test, lalu diberikan promosi kesehatan, dan pemberian kuesioner kedua yaitu post test.

\section{Metode Analisis Data}

Data diolah dengan menggunakan analisa univariat yang bertujuan untuk mengetahui distribusi frekuensi dan proporsi dari variabel motivasi responden mengenai diet hipertensi sebelum dan sesudah diberikan promosi kesehatan serta analisa tabulasi silang menggunakan perangkat lunak komputer.

Analisa bivariat digunakan untuk menyatakan analisa terhadap dua variabel, yaitu satu variabel bebas dan satu variabel terikat. Pada penelitian ini analisis yang digunakan adalah uji $\mathrm{t}$ yaitu membandingkan beda dua mean kelompok atau sampel apakah berbeda atau tidak. Uji t yang digunakan adalah uji t beda dua mean dependen karena kelompok data yang dibandingkan datanya saling mempunyai 
ketergantungan dan subjeknya sama diukur dua kali.

Setelah dilakukan pengolahan, maka data dianalisis sesuai dengan tenik atau uji analisis yang digunakan. Teknik analisis yang digunakan peneliti adalah uji $\mathrm{t}$ dependen. Setelah data dientri dan dijumlahkan, maka tahap selanjutnya adalah melakukan uji normalitas yang bertujuan untuk melihat kenormalan distribusi data dan menentukan teknik analisis apa yang akan digunakan. Uji normalitas yang digunakan adalah nilai skewness dibagi standar error. Dengan ketentuan bilamana hasilnya normal (nilai skewness dibagi standar error hasilnya kurang dari 2 dan -2) maka menggunakan uji $\mathrm{t}$ dependen parametrik, dan bilamana hasilnya tidak normal (nilai skewness dibagi standar error hasilnya lebih dari 2 dan -2) maka menggunakan uji $t$ dependen nonparametrik. Setelah dilakukan uji normalitas, hasil yang didapat adalah kedua data distribusi nilainya normal, sehingga dalam analisis data dalam penelitian ini menggunakan teknik analisis uji t dependen parametrik.
Untuk melihat nilai mean pada masing-masing variabel dapat dilihat pada tabel Paired Samples Statistics pada kolom mean dan kolom Std. Deviation untuk melihat standar deviasi pada masing-masing variabel. Sedangkan untuk melihat perbedaan nilai mean dan standar deviasi dari hasil keduanya tersebut, dapat dilihat pada tabel Paired Samples Test pada kolom mean dan pada kolom Std. Deviation.

Untuk melihat perbedaan motivasi pasien hipertensi tentang pelaksaan diet hipertensi sebelum dan sesudah di berikan promosi kesehatan di Poliklinik Penyakit Dalam RS. Rajawali Bandung dapat dilihat pada nilai $\mathrm{p}$ value pada kolom "sig(2tailed)". Uji statistik yang digunakan pada analisis ini menggunakan tingkat kemaknaan 5\% (alpha 0,05).

Setelah data diperoleh hasilnya, maka dilakukan penyimpulan atau kesimpulan data, di mana, jika p value $\leq 0,05$ maka, artinya terdapat perbedaan motivasi pasien hipertensi tentang pelaksaan diet hipertensi sebelum dan sesudah diberikan 
promosi kesehatan. Sedangkan jika $\mathrm{p}$ value > 0,05 maka, artinya tidak terdapat perbedaan motivasi pasien hipertensi tentang pelaksaan diet hipertensi sebelum dan sesudah diberikan promosi kesehatan. Sedangkan untuk melihat pengaruh dari promosi kesehatan, maka peneliti melakukan penilaian. Dimana penilaian dilakukan dengan cara :

Pengaruh $=\mathrm{Y}-\mathrm{X}$

Keterangan : Y : Nilai mean setelah perlakuan (Post Test)

$$
\text { : } \mathrm{X} \text { : Nilai mean }
$$

sebelum perlakuan (Pre Test)

Dengan ketentuan jika hasil Setelah data diperoleh hasilnya, maka dilakukan penyimpulan atau kesimpulan data, di mana, jika nilai $\mathrm{X}$ $\leq$ nilai $\mathrm{Y}$ maka promosi kesehatan berpengaruh terhadap motivasi psien hipertensi tentang pelaksanaan diet hipertensi. Sedangkan jika X > Y maka promosi kesehatan tidak berpengaruh terhadap motivasi pasien hipertensi tentang pelaksanaan diet hipertensi.

\section{HASIL PENELITIAN DAN}

1. Gambaran Motivasi Pasien Hipertensi Sebelum Dan Sesudah Diberikan Promosi Kesehatan Tentang

\section{Pelaksanaan Diet Hipertensi}

Setelah dilakukan analisis univariat mengenai motivasi pasien hipertensil sebelum dan sesudah diberikan promosi kesehatan tentang pelaksanaan diet hipertensi, didapatkan data sebagai berikut :

Tabel 1 Distribusi Frekuensi Motivasi Tentang Pelaksanaan Diet Hipertensi pada Pasien Hipertensi Sebelum Dan Sesudah di Poliklinik Penyakit Dalam RS. Rajawali Bandung

\begin{tabular}{|c|c|c|}
\hline Variabel & Frekuensi & $\begin{array}{c}\text { Persentase } \\
(\%)\end{array}$ \\
\hline \multicolumn{3}{|l|}{$\begin{array}{l}\text { Motivasi } \\
\text { (Pre Test) }\end{array}$} \\
\hline $\begin{array}{l}\text { 1. Motivasi } \\
\text { Rendah }\end{array}$ & 7 & 43.8 \\
\hline $\begin{array}{l}\text { 2. Motivasi } \\
\text { Tinggi }\end{array}$ & 9 & 56.3 \\
\hline \multicolumn{3}{|l|}{$\begin{array}{l}\text { Motivasi } \\
\text { (Post Test) }\end{array}$} \\
\hline $\begin{array}{l}\text { 1. Motivasi } \\
\text { Rendah }\end{array}$ & 5 & 31.3 \\
\hline $\begin{array}{l}\text { 2. Motivasi } \\
\text { Tinggi }\end{array}$ & 11 & 68.8 \\
\hline
\end{tabular}

Berdasarkan hasil penelitian dari 16 responden diketahui bahwa hampir seluruh responden sebelum diberikan promosi kesehatan mempunyai motivasi yang tinggi 
mengenai pelaksanaan diet hipertensi yaitu sebanyak 9 responden $(56,3 \%)$ dan hampir seluruh responden setelah diberikan pendidikan kesehatan mempunyai motivasi yang tinggi pula sebanyak 11 responden $(68,8 \%)$.

\section{Perbedaan Motivasi Pasien} Hipertensi Tentang Pelaksanaan Diet Hipertensi Sebelum Dan Sesudah Di Berikan Promosi Kesehatan.

Tabel 2 Distribusi Rata-Rata Motivasi Pasien Hipertensi Tentang Pelaksanaan Diet Hipertensi I Sebelum Dan Sesudah Diberikan Promosi Kesehatan Di Poliklinik Penyakit Dalam RS. Rajawali Bandung

\begin{tabular}{lccccc}
\hline Variabel & $\begin{array}{c}\text { Me } \\
\text { an }\end{array}$ & $\begin{array}{c}\text { Stan } \\
\text { dar } \\
\text { Devia } \\
\text { tion }\end{array}$ & $\begin{array}{c}\text { Std. } \\
\text { Error } \\
\text { Mean }\end{array}$ & $\begin{array}{c}\text { val } \\
\text { ue }\end{array}$ & $\mathbf{N}$ \\
\hline $\begin{array}{l}\text { Motivasi } \\
\text { Pretest }\end{array}$ & 1,56 & 0,512 & 0,128 & 0,43 & 16 \\
Post Test & 1,69 & 0,479 & 0,120 & 2 & \\
\hline
\end{tabular}

Hasil uji statistik didapatkan $p_{\text {value }} 0,432>\alpha(0,05)$, maka dapat disimpulkan bahwa tidak ada perbedaan yang signifikan antara motivasi pasien hipertensi mengenai pelaksanaan diet hipertensi sebelum dan sesudah di berikan promosi kesehatan.
3. Pengaruh Pendidikan Kesehatan Terhadap Pengetahuan Pekerja Seks Komersial Mengenai Penyakit Menular Seksual Sebelum Dan Sesudah Di Berikan Pendidikan Kesehatan

Sedangkan untuk melihat pengaruh dari pendidikan kesehatan, maka peneliti melakukan penilaian. Dimana penilaian dilakukan dengan cara :

$$
\text { Pengaruh }=\mathrm{Y}-\mathrm{X}
$$

Keterangan : $\mathrm{Y}$ : Nilai mean setelah perlakuan (Post Test)

$: X$ : Nilai mean

sebelum perlakuan (Pre Test)

Berdasarkan hasil penelitian didapatkan bahwa rata-rata motivasi pasien hipertensi mengenai pelaksanaan diet hipertensi sebelum diberikan promosi kesehatan adalah 1,56 sedangkan setelah diberikan promosi kesehatan mengenai pelaksanaan diet hipertensi diketahui nilai rata-rata motivasi pasien hipertensi adalah 1,69. Sehingga rentang nilai mean motivasi pasien hipertensi sebelum dan sesudah diberikan promosi kesehatan adalah 
0,17. Jadi dapat disimpulkan bahwa promosi kesehatan berpengaruh terhadap motivasi pasien hipertensi tentang pelaksanaan diet hipertensi di Poliklinik Penyakit Dalam RS. Rajawali Bandung.

\section{PEMBAHASAN}

\section{Gambaran Pengetahuan Pekerja} Seks Komersial Sebelum Dan Sesudah Diberikan Pendidikan Kesehatan Tentang Penyakit Menular Seksual

Berdasarkan hasil penelitian pada tabel 4.1 diatas, diketahui dari 16 responden bahwa hampir seluruh responden sebelum diberikan promosi kesehatan mempunyai motivasi yang tinggi mengenai pelaksanaan diet hipertensi yaitu sebanyak 9 responden $(56,3 \%)$ dan motivasi rendah sebanyak 7 responden $(43,8 \%)$. Sedangkan hampir seluruh responden setelah diberikan promosi kesehatan mempunyai motivasi yang tinggi sebanyak 11 responden $(68,8 \%)$ dan motivasi rendah sebanyak 5 responden (31,3\%). Hal tersebut menunjukkan bahwa motivasi pasien hipertensi sesudah diberikan promosi kesehatan mengalami perubahan dan peningkatan.

Motivasi berasal dari bahasa latin yang berarti to move. Secara umum mengacu pada adanya kekuatan dorongan yang menggerakkan kita untuk berperilaku tertentu. Oleh karena itu dalam mempelajari motivasi kita akan berhubungan dengan hasrat, keinginan,dorongan dan tujuan. Didalam konsep motivasi juga kita mempelajari sekelompok fenomena yang mempengaruhi sifat, kekuatan, dan ketetapan dari tingkah laku manusia (Quinn,1995 dikutip oleh Notoatmodjo, 2010)

Handoko (1998) berpendapat motivasi dibagi menjadi 2 jenis yaitu motivasi ekstrinsik dan instrinsik. Motivasi instrinsik berasal dari dalam dirinya sendiri, biasanya timbul dari perilaku yang dapat memenuhi kebutuhan sehingga manusia menjadi puas. Motivasi ekstrinsik berasal dari luar yang merupakan pengaruh dari luar atau lingkungan. Perilaku yang dilakukan dengan motivasi ekstrinsik penuh dengan kekhawatiran , 
kesangsian apabila tidak tercapai kebutuhan.

Penelitian Kharisna (2010), yang menghubungkan jus mentimun dengan hipertensi, menunjukkan bahwa penderita yang rajin mengonsumsi jus mentimun secara teratur dapat menurunkan tekanan darah. Hasil penelitian yang dilakukan oleh Mardiyati (2009) juga menunjukan bahwa kepatuhan penderita hipertensi dalam menjalankan diet hipertensi seperti diet rendah garam dapat mencegah timbulnya penyakit hipertensi. Dari penelitian tersebut dapat disimpulkan bahwa, perilaku berkaitan dengan kebiasaan yang dapat menghasilkan suatu yang bersifat positif maupun negatif. Sehingga perilaku penderita hipertensi yang secara rutin mengkonsumsi jus mentimun dapat menurunkan tekanan darah dalam tubuh penderita hipertensi, dan perilaku penderita yang menghindari konsumsi garam setiap harinya dapat mencegah timbulnya penyakit hipertensi. Begitu juga dalam penelitian ini, menunjukkan bahwa pengetahuan, motivasi dan sikap seseorang mempengaruhi penderita hipertensi untuk berperilaku/bertindak patuh tidaknya terhadap diet hipertensi.

Keluarga berfungsi sebagai sistem pendukung bagi anggotanya. Anggota keluarga juga memandang bahwa orang yang bersifat mendukung selalu siap memberikan pertolongan dan bantuan jika diperlukan. Dukungan keluarga adalah sikap, tindakan dan penerimaan keluarga terhadap penderita yang sakit. Dukungan keluarga merupakan suatu bentuk perhatian, dorongan yang didapatkan individu dari orang lain melalui hubungan interpersonal yang meliputi perhatian, emosional dan penilaian. Keluarga dipandang sebagai suatu sistem, jika terjadi gangguan pada salah satu anggota keluarga dapat mempengaruhi seluruh sistem. Sebaliknya disfungsi keluarga dapat pula menjadi salah satu penyebab terjadinya gangguan pada anggota keluarga (Purwanto, 2005).

Dukungan petugas kesehatan sangatlah besar bagi penderita, dimana petugas adalah pengelola penderita sebab petugas adalah yang paling 
sering berinteraksi, sehingga pemahaman terhadap kondisi fisik maupun psikis menjadi lebih baik dengan sering baik. Sehingga dapat mempengaruhi rasa percaya dan menerima kehadiran petugas kesehatan dapat ditumbuhkan dalam diri penderita dengan baik.

Hubungan yang telah lama dilakukan seseorang sebagai pasien, bidan, perawat atau dokter (sebagai tenaga kesehatan) akan memiliki pengaruh terhadap tingkat kepatuhan yang diberikan kepada tenaga kesehatan. Pasien yang telah mengenal dengan baik terhadap tenaga kesehatan tempat berobat, maka akan cenderung lebih patuh dari pada terhadap mereka yang belum begitu kenal begitu pula penanganan oleh tenaga kesehatan terhadap pasiennya akan cenderung dipatuhi saran-sarannya dari pada mereka yang kurang ramah dan sebagainya Hasil penelitian diatas kemungkinan disebabkan karena adanya dukungan dari keluarga dalam pelaksanaan diet hipertensi yang mempengaruhi dorongan yang timbul dari dalam diri pasien hipertensi sehingga pasien merasa termotivasi untuk melakukan diet hipertensi. Dalam hal ini dukungan keluarga merupakan sumber motivasi ekstrinsik bagi pasien hipertensi yang mempunyai peranan penting dalam membangkitkan motivasi instrinsik dari pasien hipertensi agar mau melakukan diet hipertensi. Menurut Handoko (2001) motivasi instrinsik merupakan dorongan yang timbul dari diri pasien dalam melakukan suatu tindakan berupa dorongan untuk menghindari risiko yang dihadapi, mengatasi rintangan, menyesuaikan kamampuan diri terhadap orang lain, mempelajari orang lain serta dorongan mencari jalan lain dalam melakukan suatu tindakan, misalnya minat, kebutuhan dan kepercayaan.

\section{Perbedaan Motivasi Pasien Hipertensi Mengenai} Pelaksanaan Diet Hipertensi Sebelum Dan Sesudah Di Berikan Promosi Kesehatan.

Hasil penelitian menunjukkan bahwa palue $0,432>\alpha(0,05)$, maka dapat disimpulkan bahwa tidak ada perbedaan yang signifikan antara 
motivasi pasien hipertensi mengenai pelaksanaan diet hipertensi sebelum dan sesudah di berikan promosi kesehatan.

$$
\text { Morgan (1986) dalam }
$$

Notoatmodjo (2010) menggambarkan, jika keadaan internal seseorang tidak seimbang maka individu akan terdorong untuk melakukan suatu tindakan atau perilaku untuk mencapai suatu tujuan, dimana jika tujuan tersebut tercapai maka akan terjadinya keseimbangan yang menyebabkan seseorang akan merasa puas atau lega. Jika kebutuhan sudah terpenuhi, maka ketegangan akan menurun dan kondisi menjadi seimbang kembali.

Wood (1926, dan Join Commision On Health Education, 1973, dalam Fitriani, 2011) menjelaskan bahwa promosi kesehatan merupakan kegiatan-kegiatan yang ditujukan untuk meningkatkan kemampuan seseorang dan membuat keputusan yang tepat sehubungan dengan pemeliharaan kesehatan, sehingga berdasarkan pengalamanpengalaman yang diperoleh dapat bermanfaat dalam mempengaruhi pengetahuan dan motivasi seseorang. Peningkatan motivasi melalui pemberian promosi kesehatan ini pada dasarnya memang sesuai dengan hasil penelitian ini, dimana promosi kesehatan berpengaruh terhadap peningkatan motivasi yang dapat dilihat dari perbedaan nilai mean yang ada. Akan tetapi masih terdapat beberapa responden yang tidak mengalami peningkatan motivasi atau mempunyai tingkat motivasi yang sama. Hal tersebut dikarenakan penerimaan informasi pada setiap orang itu berbeda. Dimana penerimaan informasi sebagai motivasi menurut Notoatmodjo (2007) dapat dipengaruhi oleh faktor umur, pendidikan, dan pengalaman yang pernah diperoleh.

\section{Pengaruh Promosi Kesehatan Terhadap Motivasi Pasien Hipertensi Mengenai} Pelaksanaan Diet Hipertensi Sebelum Dan Sesudah Di Berikan Promosi Kesehatan

Berdasarkan hasil penelitian didapatkan bahwa rata-rata motivasi pasien hipertensi mengenai 
pelaksanaan diet hipertensi sebelum diberikan promosi kesehatan adalah 1,56 sedangkan setelah diberikan promosi kesehatan mengenai pelaksanaan diet hipertensi diketahui nilai rata-rata motivasi pasien hipertensi adalah 1,69. Sehingga rentang nilai mean motivasi pasien hipertensi sebelum dan sesudah diberikan promosi kesehatan adalah 0,17 . Jadi dapat disimpulkan bahwa promosi kesehatan berpengaruh terhadap motivasi pasien hipertensi tentang pelaksanaan diet hipertensi di Poliklinik Penyakit Dalam RS. Rajawali Bandung.

WHO (1954), sebagaimana dikutip oleh Notoatmodjo S (2007), bahwa pemberian promosi kesehatan adalah suatu upaya untuk menciptakan perilaku masyarakat yang kondusif untuk kesehatan, artinya promosi kesehatan berupaya agar masyarakat mengetahui atau menyadari bagaimana memelihara kesehatan mereka. Lebih dari itu promosi kesehatan pada akhirnya bukan hanya sekedar meningkatkan pengetahuan masyarakat, namun yang lebih penting adalah mencapai perilaku kesehatan (health behaviour) yang didasari dengan pengetahuan yang baik dan tepat.

Hal tersebut sejalan dengan pendapat Craven dan Hirnle (1996, dalam Herawani, 2011) menjelaskan bahwa promosi kesehatan adalah penambahan pengetahuan dan kemampuan seseorang melalui teknik praktik belajar atau intruksi, dengan tujuan untuk mengingat fakta atau kondisi nyata, dengan cara memberikan dorongan terhadap pengarahan diri (self direction), aktif memberikan informasi-informasi atau ide baru.

Fitriani (2011) menjelaskan bahwa promosi kesehatan dapat mempengaruhi seseorang dalam memiliki pengetahuan dan motivasi tentang ilmu kesehatan, termasuk cara hidup sehat dan teratur, sehingga mereka mengerti dan dapat menerapkan prinsip-prinsip pencegahan penyakit dalam kaitannya dengan kesehatan dan keselamatan dalam kehidupan sehari-hari. Oleh sebab itu seseorang yang telah 
mendapatkan informasi atau pengetahuan melalui pemberian pendidikan kesehatan dapat juga memiliki nilai, sikap dan motivasi yang positif terhadap prinsip hidup sehat, serta memiliki keterampilan dalam melaksanakan hal yang berkaitan dengan pemeliharaan, pertolongan, dan perawatan kesehatan.

Rogers (1974, dalam Notoatmodjo, 2007) menjelaskan bahwa perilaku yang didasari oleh pengetahuan akan lebih langgeng daripada perilaku yang tidak didasari oleh pengetahuan. Apabila penerimaan perilaku baru atau adopsi perilaku didasari oleh pengetahuan, pemahaman, kesadaran, dan sikap positif, maka perilaku tersebut akan bersifat lenggeng (long lasting). Sebaliknya apabila perilaku tidak didasari oleh pengetahuan, pemahaman dan kesadaran maka tidak akan berlan

\section{SIMPULAN}

Berdasarkan analisis data dan pembahasan hasil penelitian mengenai pengaruh promosi kesehatan terhadap motivasi pasien hipertensi tentang pelaksanaan diet hipertensi di
Poliklinik Penyakit Dalam RS. Rajawali Bandung pada 16 responden, maka dapat diambil kesimpulan sebagai berikut :

1. Hampir seluruh responden sebelum diberikan promosi kesehatan mempunyai motivasi yang tinggi mengenai pelaksanaan diet hipertensi yaitu sebanyak 9 responden $(56,3 \%)$ dan motivasi rendah sebanyak 7 responden $(43,8 \%)$. Sedangkan hampir seluruh responden setelah diberikan promosi kesehatan mempunyai motivasi yang tinggi sebanyak 11 responden $(68,8 \%)$ dan motivasi rendah sebanyak 5 responden $(31,3 \%)$.

2. Tidak ada perbedaan yang signifikan antara motivasi pasien hipertensi mengenai pelaksanaan diet hipertensi sebelum dan sesudah di berikan promosi kesehatan dengan nilai $p_{\text {value }} 0,432$ $>\alpha(0,05)$

3. Terdapat pengaruh promosi kesehatan terhadap motivasi pasien hipertensi tentang pelaksanaan diet hipertensi di 
Poliklinik Penyakit Dalam RS.

Rajawali Bandung, dimana nilai mean pre test adalah 1,56 dan nilai post test adalah 1,69. Sehingga didapatkan perbedaan nilai ratarata (mean) antara pengukuran pertama (pretest) dan kedua (posttest) adalah 0,13

\section{SARAN}

\section{Bagi Pasien Hipertensi}

Hasil penelitian ini diharapkan dapat dijadikan bahan pertimbangan untuk meningkatkan motivasi pasien terhadap diet hipertensi

\section{Bagi Petugas Kesehatan}

Hasil penelitian ini diharapkan dapat dijadikan bahan informasi untuk meningkatkan upaya promosi kesehatan dalam memotivasi pasien hipertensi untuk selalu memperhatikan pelaksanaan dietnya

\section{Bagi Peneliti Selanjutnya}

Bagi peneliti selanjutnya disarankan agar dapat lebih mengembangkan pemikiran dan kreatifitas sehingga dapat mengupas segala permasalahan tentang Pelaksanan diet hipertensi. Cara pengumpulan data dapat dilakukan dengan metode yang berbeda misalnya Focus Group Discussion, In Depth Interview atau metode lain yang dianggap lebih sesuai, sehingga didapatkan hasil yang lebih bervariasi. Penelitian harus benar-benar dipersiapkan antara lain mengenai pilihan lokasi penelitian, reponden, cara maupun alat pengumpul data dan segala sesuatu yang berhubungan dengan jalannya penelitian. Hal tersebut bertujuan agar penelitian yang dilakukan dapat sesuai dengan keadaan respoden serta menambah wawasan ilmu pengetahuan.

\section{DAFTAR PUSTAKA}

Arikunto. (2006). Prosedur Penelitian suatu pendekatan praktek. Jakarta : Reneka Cipta.

Braverman ER. (2006).Penyakit jantung \& penyehatannya secara alami. Jakarta: PT Bhuana Ilmu Populer

Budiarto, E. 2001. Penelitian Epidemiologi. Jakarta : Salemba Medika Dinas Kesehatan Propinsi Jawa Barat. 2010. Profil Kesehatan Propinsi Jawa Barat. Bandung : Dinkes Jawa barat.

Handoko, (2001). Konsep Dasar Motivasi dan Perilaku. Jakarta : Salemba Medika 
Hidayat, AA. (2004). Pengantar

Keperawatan. Jakarta : Salemba Medika (2007). Metode Penelitian Keperawatan dan Teknik analisa data. Salemba Medika

Hasibuan. (2003) Manajemen Sumber Daya Manusia edisi revisi. Jakarta : Sinar Grafika Offset

Leksokumoro N. (2009). Intisari menu sehat. Jakarta : Gramedia

Nursalam. 2001. Proses dan

Dokumentasi Keperawatan. Edisi Pertama. Jakarta : Salemba Medika.

Nursalam. (2002). Manajemen

Keperawatan. Salemba Medika Jakarta (2007) Konsep dan penerapan Metodologi Penelitian Ilmu keperawatan. Jakarta : Salemba medika.

Notoatmodjo. (2003). Metode Penelitian Klinis. Jakarta : Rineka Cipta (2007). Promosi Kesehatan dan Ilmu Perilaku. Jakarta: Rineka Cipta

Mansjoer, Arif, et all. 2001. Kapita Selekta Kedokteran. Edisi 3. Jilid 2. Jakarta : Media Aesculapius.
Padwanita K. (2001). Pengendalian

hipertensi. Bandung : ITB

Pearce, Evelyn C. 2002. anatoni fisiologi untuk para medis. Jakarta : PT Gramedia

Persatuan Ahli Gizi Indonesia. 2001. Penuntun Diit Edisi 2. Jakarta : Gramedia.

Purwati, dkk. (2004). Perencaan menu untuk penderita tekanan darah tinggi. Jakarta : PT Penebar Swadaya

Riyanto, A. (2009). Pengolahan dan Analisis Data Kesehatan. Bandung : Nuha Medika

Rokhaeni, Heni. 2001. Buku Ajar Keperawatan Kardiovaskuler. Jakarta : Bidang Pendidikan Pelatihan Pusat Kesehatan Jantung dan Pembuluh Darah Nasional Harapan Kita.

Tarwoto \& Wartonah. 2003. Kebutuhan Dasar Manusia \& Proses Keperawatan. Jakarta : Salemba Medika.

Winardi. (2001). Motivasi dan pemotivasianya. Jakarta : Bumi Aksara Waspadji,Soparman; Waspadji, Sarwono, (2006). Buku Ajar Ilmu Penyakit Dalam, Jakarta : Fakultas Kedokteran Universitas Indonesia. 
